\title{
Snoring in primary school children and domestic environment: A Perth school based study Guicheng Zhang*1, Jeffery Spickett ${ }^{1}$, Krassi Rumchev ${ }^{1}$, Andy H Lee ${ }^{1}$ and Stephen Stick ${ }^{2}$
}

Address: ${ }^{1}$ School of Public Health, Curtin University of Technology, GPO Box U1987, Perth, WA 6845, Australia and ${ }^{2}$ Department of Respiratory Medicine, Princess Margaret Hospital for Children, Roberts Road, Subiaco, WA 6008, Australia

Email: Guicheng Zhang* - zhangg@exchange.curtin.edu.au; Jeffery Spickett - J.Spickett@curtin.edu.au;

Krassi Rumchev - Rumchev@exchange.curtin.edu.au; Andy H Lee - Andy.lee@curtin.edu.au; Stephen Stick - Stephen.Stick@health.wa.gov.au

* Corresponding author

Published: 04 November 2004

Respiratory Research 2004, 5:19 doi:10.1186/1465-9921-5-19
Received: 27 July 2004

Accepted: 04 November 2004

This article is available from: http://respiratory-research.com/content/5/1/19

(C) 2004 Zhang et al; licensee BioMed Central Ltd.

This is an Open Access article distributed under the terms of the Creative Commons Attribution License (http://creativecommons.org/licenses/by/2.0), which permits unrestricted use, distribution, and reproduction in any medium, provided the original work is properly cited.

\begin{abstract}
Background: The home is the predominant environment for exposure to many environmental irritants such as air pollutants and allergens. Exposure to common indoor irritants including volatile organic compounds, formaldehyde and nitrogen dioxide, may increase the risk of snoring for children. The aim of this study was to investigate domestic environmental factors associated with snoring in children.
\end{abstract}

Methods: A school-based respiratory survey was administered during March and April of 2002. Nine hundred and ninety six children from four primary schools within the Perth metropolitan area were recruited for the study. A sub-group of 88 children aged 4-6 years were further selected from this sample for domestic air pollutant assessment.

Results: The prevalences of infrequent snoring and habitual snoring in primary school children were $24.9 \%$ and $15.2 \%$ respectively. Passive smoking was found to be a significant risk factor for habitual snoring (odds ratio $(O R)=1.77 ; 95 \%$ confidence interval $(\mathrm{Cl})$ : I.20-2.6I), while having pets at home appeared to be protective against habitual snoring (OR $=0.58 ; 95 \% \mathrm{Cl}: 0.37-0.92$ ). Domestic pollutant assessments showed that the prevalence of snoring was significantly associated with exposure to nitrogen dioxide during winter. Relative to the low exposure category $(<30 \mu \mathrm{g} /$ $\left.\mathrm{m}^{3}\right)$, the adjusted ORs of snoring by children with medium $\left(30-60 \mu \mathrm{g} / \mathrm{m}^{3}\right)$ and high exposures $(>$ $\left.60 \mu \mathrm{g} / \mathrm{m}^{3}\right)$ to $\mathrm{NO}_{2}$ were $2.5(95 \% \mathrm{Cl}: 0.7-8.7)$ and $4.5(95 \% \mathrm{Cl}: 1.4-14.3)$ respectively. The corresponding linear dose-response trend was also significant $(\mathrm{P}=0.0 \mathrm{I} \mathrm{I})$.

Conclusion: Snoring is common in primary school children. Domestic environments may play a significant role in the increased prevalence of snoring. Exposure to nitrogen dioxide in domestic environment is associated with snoring in children.

\section{Background}

Snoring occurs when there is an obstruction to the free flow of air through the airways at the back of the mouth and nose. The prevalence of habitual snoring in children has been reported to vary between 3.2 and $11 \%$. Infrequent snoring is present in $17-27 \%$ of all children [1-3]. 
A study of young Australian children (2-5 years old) found the prevalence of snoring to be $10.5 \%$ [4].

Approximately one third of children who snore regularly have obstructive sleep apnea syndrome (OSAS) [5]. A few studies have claimed that snoring in children can affect neurocognitive function, behaviour and blood pressure to some extent even in the absence of apnea [6,7]. Thus, concerns about causes of snoring and prevention strategies for children have arisen among both professional medical workers and parents.

Numerous risk factors for snoring and OSAS have been reported including enlarged adenoids and/or tonsils, obesity, allergies or other causes of nasal obstruction, and exposure to environmental tobacco smoke (ETS) [8-10]. However, there has been very little research on exposure to environmental irritants, other than ETS, as contributing factors for snoring in children. The home is the predominant environment for exposure to many environmental irritants such as allergens and air pollutants. We hypothesized that high levels of exposure to common indoor irritants including volatile organic compounds, formaldehyde and nitrogen dioxide, could increase the risk of snoring. The aim of this study, therefore, was to investigate domestic environmental factors associated with snoring in children.

\section{Methods}

\section{Study design}

Nine hundred and ninety-six (996) school children, aged between 4 and 12 years, were recruited from four primary schools within the Perth metropolitan area. Parents/ guardians of the children completed a questionnaire related to respiratory health of their children and domestic environments. A sample of 88 children, aged 4-6 years, was then selected randomly to participate in an indoor air quality assessment of their domestic environments. Ethics approval was obtained from the Human Research Ethics Committee of Curtin University of Technology.

\section{Respiratory survey}

The survey instrument adopted was taken from a questionnaire on respiratory health and indoor air quality [11]. Some questions related to respiratory symptoms and domestic environments have been modified in order to conform to the study objectives. The questionnaire included two parts: the first part covered questions related to children's health and demographic characteristics, the second part consisted of questions about the home environment. Several terms relevant to the study were defined as follows. Children who had asthma were classified as "ever asthma", while those reported having asthma attack or taking any asthma medication within the past 12 months were regarded as "current asthma". Children who had coughed up phlegm on most days over a period of three months were referred to having "chronic productive cough. "habitual snoring" was defined as snoring more than 4 times per week, whereas "infrequent snoring" meant snoring less than 4 times per week. In this context, "snoring" included both "habitual snoring" and "infrequent snoring".

The questionnaires were distributed to parents by school teachers and later collected from the classrooms. The survey was conducted between March and April 2002. A consent form was signed by each participating parent or guardian. The response rate was $62.5 \%$.

\section{Domestic air pollutant assessment}

A sample of 88 year one and pre-primary students was randomly selected from participants of the respiratory survey for domestic air pollutant monitoring. Among them, $34(38.6 \%)$ children were snorers (20 habitual and 14 infrequent). Two home visits were subsequently carried out during the winter of 2002 and summer of 2003 to measure indoor volatile organic compounds (VOCs), formaldehyde and nitrogen dioxide levels.

VOCs were collected in the living room by active sampling using charcoal sorbent tubes. The air-sampling rate was 1 $\mathrm{L} / \mathrm{min}$ with sampling undertaken for 10 hours during daytime. The analyses were performed using a Perkin Elmer Autosystem XL gas chromatograph equipped with a flame ionization detector. Eleven common compounds were identified and quantified by comparing the retention times: benzene, chlorobenzene, 1,2-dichlorobenzene, 1,3-dichlorobenzene, 1,4-dichlorobenzene, ethylbenzene, styrene, toluene, m-xylene, o-xylene and p-xylene. Their total amount was expressed as total VOCs (TVOCs). Formaldehyde $(\mathrm{HCHO})$ and nitrogen dioxide $\left(\mathrm{NO}_{2}\right)$ were collected by a passive sampling method in both the living room and the child's bedroom for 24 hours. Formaldehyde was analyzed using high-performance liquid chromatography [12].

Nitrogen dioxide was analyzed by a photometric method [13]. The method utilized a Palmes diffusion tube, containing stainless steel screens coated with trithanolamine (TEA), which was used as an absorbent. The concentrations of $\mathrm{NO}_{2}$ were measured based on the quantity of the nitrogen dioxide gas transferred through the tube to the absorbent by molecular diffusion during a given exposure period $[14,15]$.

\section{Data entry and statistics analysis}

Preliminary data screening and cleaning were conducted prior to statistical analysis. Associations between the prevalence of snoring and environmental and geographic factors and respiratory symptoms were examined using Chi- 
square tests. Multivariate logistic regression analysis was undertaken to estimate the risk of snoring adjusting for possible confounders. Since the distributions of VOCs, $\mathrm{HCHO}$ and $\mathrm{NO}_{2}$ were positively skewed, geometric means (GM) of these variables were calculated after applying a logarithmic transformation. All statistical analyses were performed using the SPSS package Version 10.0.

\section{Results}

Of the 996 participants, 985 children (98.9\%) had intact records for snoring. There were 248 children $(24.9 \%$; $95 \%$ CI: $21.2 \%-28.6 \%)$ reported infrequent snoring and 151 children (15.2\%; 95\% CI: $12.6 \%-17.8 \%$ ) suffered from habitual snoring.

\section{Snoring by age and gender}

Table 1 shows the prevalence of infrequent and habitual snoring by age and gender. Boys had a slightly higher rate of snoring than girls, but the difference was not statistically significant. The rates of habitual snoring decreased significantly with age $(P=0.03)$.

The prevalences of respiratory symptoms, asthma and other allergic conditions were significantly different among non-snoring, infrequent snoring, and habitual snoring children, with habitual snorers having the highest rates. Results are presented in Table 2. A significant association $(P<0.001)$ was evident between snoring and respiratory symptoms, asthma and other allergic conditions.

\section{Snoring and household characteristics}

Table 3 shows the proportion rates of various household characteristics. The snoring and non-snoring groups were similar in terms of "gas cooking", "dampness at home" and "carpet in child's bedroom". However, children suffering from infrequent snoring or habitual snoring were more likely to live in "smoking" households $(\mathrm{P}=0.004)$. Children with pets at home seemed to be less likely to develop habitual snoring $(\mathrm{P}=0.02)$.

To further investigate the impact of passive smoking and pet ownership on snoring, logistic regression analysis was undertaken, controlling for confounders age, gender, asthma and other allergic conditions. The results indicated that passive smoking increased the risk of habitual snoring significantly $(\mathrm{OR}=1.77 ; 95 \% \mathrm{CI}: 1.20-2.61)$, while having pets decreased the risk (OR $=0.58$; 95\% CI: 0.37-0.92). However, the corresponding effects of passive smoking and pet ownership on infrequent snoring were statistically not significant. The Hosmer-Lemeshow statistic confirmed adequacy of the fitted logistic regression model $(\mathrm{P}>0.10)$.
Table I: Prevalence of infrequent and habitual snoring by age and gender

\begin{tabular}{|c|c|c|c|c|c|c|c|}
\hline & \multicolumn{6}{|c|}{ Gender } & \multirow[b]{3}{*}{$P$} \\
\hline & \multicolumn{2}{|c|}{ Boys } & \multicolumn{4}{|c|}{ Girls } & \\
\hline & $\mathrm{n}$ & $\%$ & \multicolumn{2}{|c|}{$\mathrm{n}$} & \multicolumn{2}{|c|}{$\%$} & \\
\hline Infrequent snoring & 130 & 25.9 & \multicolumn{2}{|c|}{118} & \multicolumn{2}{|c|}{24.4} & $>0.05$ \\
\hline \multirow[t]{4}{*}{ Habitual snoring } & 82 & 16.3 & \multirow{2}{*}{\multicolumn{2}{|c|}{$\begin{array}{c}69 \\
\text { Age }\end{array}$}} & \multicolumn{2}{|c|}{14.3} & $>0.05$ \\
\hline & & & & & & & \\
\hline & \multicolumn{2}{|c|}{$<7$ years } & \multicolumn{2}{|c|}{$7-9$ years } & \multicolumn{2}{|c|}{$>9$ years } & $P$ \\
\hline & $\mathrm{n}$ & $\%$ & $\mathrm{n}$ & $\%$ & $\mathrm{n}$ & $\%$ & \\
\hline Infrequent snoring & 77 & 26.6 & 70 & 25.5 & 100 & 24.0 & $>0.05$ \\
\hline Habitual snoring & 58 & 20.1 & 42 & 15.3 & 51 & 12.2 & 0.03 \\
\hline
\end{tabular}

\section{Snoring and indoor pollutant exposure}

The levels of pollutants exposure were similar between houses of habitual snorers and houses of infrequent snorers. To facilitate analysis, data from the two groups were combined to improve statistical power for comparison with houses of the non-snoring children. Table 4 shows the pollutant measurements. The levels of TVOCs and $\mathrm{HCHO}$ were not significantly different between houses of snorers and non-snorers regardless of season. However, the geometric means of $\mathrm{NO}_{2}$ concentration in the living rooms of snoring children were higher. In particular, the levels of $\mathrm{NO}_{2}$ in snoring children's bedroom were significantly higher than those in non-snoring children's bedroom during winter.

Recognizing that the main source of indoor $\mathrm{NO}_{2}$ could be a gas heater and/or gas cooker, we compared $\mathrm{NO}_{2}$ concentration between houses with and without a gas heater in the child's bedroom. The results confirmed that $\mathrm{NO}_{2}$ levels (GM: $49 \mu \mathrm{g} / \mathrm{m}^{3}, 95 \% \mathrm{CI}: 37-65 \mu \mathrm{g} / \mathrm{m}^{3}$ ) in houses with a gas heater were significantly higher than those (GM: 27 $\mu \mathrm{g} / \mathrm{m}^{3}, 95 \% \mathrm{CI}: 20-38 \mu \mathrm{g} / \mathrm{m}^{3}$ ) recorded in houses without a gas heater.

Logistic regression analysis was next conducted to assess the dose-response relationship between bedroom exposure to $\mathrm{NO}_{2}$ during winter and snoring in children.

Based on the empirical $\mathrm{NO}_{2}$ distribution, the monitored households were classified as: 'low' exposure $(<30 \mu \mathrm{g} /$ $\left.\mathrm{m}^{3}\right)$, 'medium' exposure $\left(30-60 \mu \mathrm{g} / \mathrm{m}^{3}\right)$ and 'high' exposure $\left(>60 \mu \mathrm{g} / \mathrm{m}^{3}\right)$. After adjusting for age, gender, asthma, passive smoking and pet ownership, domestic $\mathrm{NO}_{2}$ exposure level was still positively associated with snoring, the ORs being 2.5 (95\% CI: 0.7-8.7) for medium exposure and 4.5 (95\% CI: 1.4-14.3) for high exposure. There was also evidence of a linear dose-response relationship ( $\mathrm{P}=$ 0.011 for trend). 
Table 2: Snoring and respiratory symptoms, asthma and other allergic conditions

\begin{tabular}{|c|c|c|c|c|c|c|c|}
\hline & \multicolumn{2}{|c|}{$\begin{array}{l}\text { Non-snoring } \\
(N=586)\end{array}$} & \multicolumn{2}{|c|}{$\begin{array}{l}\text { Infrequent snoring } \\
\qquad(N=248)\end{array}$} & \multicolumn{2}{|c|}{$\begin{array}{l}\text { Habitual snoring } \\
\quad(N=|5|)\end{array}$} & \multirow[b]{2}{*}{$P$} \\
\hline & $\mathrm{n}$ & $\%$ & $\mathrm{n}$ & $\%$ & $\mathrm{n}$ & $\%$ & \\
\hline Phlegm with a cold & 145 & 24.7 & 97 & 39.1 & 66 & 44.0 & $<0.001$ \\
\hline Phlegm without a cold & 38 & 6.5 & 31 & 12.5 & 25 & 16.6 & $<0.001$ \\
\hline Chronic productive cough & 12 & 2.1 & 13 & 5.2 & 14 & 9.3 & $<0.001$ \\
\hline Wheeze during or after exercise & 71 & 12.1 & 54 & 21.8 & 37 & 24.5 & $<0.001$ \\
\hline Wheeze without exercise & 47 & 8.0 & 27 & 10.9 & 26 & 17.2 & $<0.001$ \\
\hline Any current wheeze & 110 & 18.8 & 83 & 33.5 & 59 & 39.3 & $<0.001$ \\
\hline Dry cough at night without a cold & 134 & 22.9 & 98 & 39.7 & 66 & 43.7 & $<0.001$ \\
\hline Ever asthma & 140 & 23.9 & 86 & 34.7 & 56 & 37.1 & $<0.001$ \\
\hline Current asthma & 83 & 14.3 & 62 & 25.0 & 36 & 24.2 & $<0.001$ \\
\hline Allergic rhinitis or hay fever & 217 & 37.6 & 123 & 49.6 & 92 & 61.7 & $<0.001$ \\
\hline
\end{tabular}

Table 3: Snoring and household characteristics

\begin{tabular}{|c|c|c|c|c|c|c|c|c|}
\hline & \multirow[b]{2}{*}{$\mathrm{N}$} & \multicolumn{2}{|c|}{ Non-snoring } & \multicolumn{2}{|c|}{ Infrequent snoring } & \multicolumn{2}{|c|}{ Habitual snoring } & \multirow[b]{2}{*}{$\mathrm{P}$} \\
\hline & & $\mathrm{n}$ & $\%$ & $\mathrm{n}$ & $\%$ & $\mathrm{n}$ & $\%$ & \\
\hline \multicolumn{9}{|l|}{ Type of cooking } \\
\hline Gas cooking & 565 & 331 & 57.5 & 155 & 63.0 & 79 & 53.0 & $>0.05$ \\
\hline Electric cooking & 221 & 142 & 24.7 & 43 & 17.5 & 36 & 24.2 & $>0.05$ \\
\hline Gas and electric cooking & 185 & 103 & 17.9 & 48 & 19.5 & 34 & 22.8 & $>0.05$ \\
\hline \multicolumn{9}{|l|}{ Dampness at home } \\
\hline Damp patch & 85 & 49 & 8.5 & 25 & 10.2 & 11 & 7.5 & $>0.05$ \\
\hline Condensation & 273 & 153 & 26.7 & 74 & 30.2 & 46 & 30.7 & $>0.05$ \\
\hline Mould & 167 & 92 & 18.1 & 42 & 19.2 & 33 & 24.1 & $>0.05$ \\
\hline \multicolumn{9}{|l|}{ Other characteristics } \\
\hline Carpet in child's bedroom & 827 & 491 & 83.9 & 208 & 84.2 & 128 & 85.3 & $>0.05$ \\
\hline Smoking household & 432 & 235 & 41.3 & 113 & 46.3 & 84 & 56.4 & 0.004 \\
\hline Pet at home & 787 & 474 & 82.7 & 203 & 83.2 & 110 & 73.3 & 0.022 \\
\hline
\end{tabular}

Table 4: Snoring and indoor pollutants

\begin{tabular}{|c|c|c|c|c|c|c|c|c|c|c|}
\hline & & \multirow[b]{2}{*}{$\mathrm{n}^{\prime}$} & \multicolumn{3}{|c|}{ Houses of non-snoring children } & \multicolumn{4}{|c|}{ Houses of snoring children } & \multirow[b]{2}{*}{$P$} \\
\hline & & & $\mathrm{GM}^{2}$ & Min & Max & $n^{\prime}$ & $\mathrm{GM}^{2}$ & Min & Max & \\
\hline \multicolumn{11}{|l|}{ TVOCs } \\
\hline \multirow[t]{2}{*}{ Living room } & Summer & 47 & 11 & 1 & 254 & 32 & 15 & 2 & 204 & $>0.05$ \\
\hline & Winter & 52 & 15 & I & 247 & 34 & 22 & 1 & 575 & $>0.05$ \\
\hline \multicolumn{11}{|l|}{$\mathrm{HCHO}$} \\
\hline \multirow[t]{2}{*}{ Living room } & Summer & 48 & 7 & ND & 34 & 32 & 6 & ND & 26 & $>0.05$ \\
\hline & Winter & 51 & 15 & 2 & 92 & 33 & 19 & ND & 92 & $>0.05$ \\
\hline \multirow[t]{2}{*}{ Bedroom } & Summer & 48 & 9 & ND & 126 & 32 & 8 & ND & 47 & $>0.05$ \\
\hline & Winter & 49 & 16 & 2 & 84 & 33 & 18 & 2 & 98 & $>0.05$ \\
\hline \multicolumn{11}{|l|}{$\mathrm{NO}_{2}$} \\
\hline \multirow[t]{2}{*}{ Living room } & Summer & 48 & 37 & 11 & 244 & 32 & 41 & 8 & 511 & $>0.05$ \\
\hline & Winter & 51 & 38 & 9 & 314 & 32 & 48 & 6 & 345 & $>0.05$ \\
\hline \multirow[t]{2}{*}{ Bedroom } & Summer & 48 & 32 & 6 & 293 & 32 & 31 & 6 & 199 & $>0.05$ \\
\hline & Winter & 50 & 33 & 6 & 267 & 32 & 56 & 8 & 511 & 0.015 \\
\hline
\end{tabular}

ND $=$ not detectable

I Missing data or lost to follow-up present

${ }^{2}$ Geometric mean of pollutant concentration $\left(\mu \mathrm{g} / \mathrm{m}^{3}\right)$ 


\section{Discussion}

Snoring is an important symptom and major risk factor for obstructive sleep apnea [5]. Several studies in Italy and Thailand reported that the prevalence of habitual snoring varied from 4.9 to $34.5 \%$ in primary school children $[5,16,17]$, while the prevalence of snoring was $10.5 \%$ according to a study of Australian children aged $2-5$ years [4]. The present study found the prevalence of habitual snoring among primary school children in Perth was $15.2 \%$, and $24.9 \%$ of the children had infrequent snoring. The total prevalence of snoring was $40.1 \%$. That the participants had high rates of current asthma (18.7\%) and allergy (44.0\%) (allergic rhinitis or hay fever) may explain the apparently high snoring prevalence taking into account the link between snoring and asthma and allergy.

The prevalence of snoring among older children was significantly lower than that of younger children. No significant difference in snoring prevalence between boys and girls was observed, which appeared to be consistent with the literature $[16,18]$.

Strong associations were also found between snoring and respiratory symptoms, asthma and other allergic conditions, as in previous studies $[10,19,20]$.

In relation to the domestic environment, passive smoking was identified as a major risk factor for habitual snoring and consistent with other studies [10,21]. An interesting finding was the observed inverse relationship between snoring and pet ownership. There is evidence in the literature suggesting that pet ownership in early life can protect against the development of allergic disease [22]. Although the protective effect of pet ownership on habitual snoring was significant after controlling for allergic diseases, the mechanism that led to a lower risk of snoring remains to be investigated.

Unlike TVOCs and HCHO, it appears that domestic exposure to $\mathrm{NO}_{2}$ was significantly associated with snoring. It should be remarked that the low exposure threshold was set below the annual value of $40 \mu \mathrm{g} / \mathrm{m}^{3}$ recommended by WHO [23], whereas the high exposure cut off is higher than the guideline value. Our results suggested that high exposure to $\mathrm{NO}_{2}$ could increase the risk of snoring by 4.5 times. A previous study reported that children aged 5-12 years had a $20 \%$ increased risk of respiratory symptoms and disease for each increase of $28.3 \mu \mathrm{g} / \mathrm{m}^{3}$ in $\mathrm{NO}_{2}$ concentrations (2-week average), when the weekly average concentrations were in the range $15-128 \mu \mathrm{g} / \mathrm{m}^{3}$ or possibly higher [23]. Another study in Australia confirmed the link between $\mathrm{NO}_{2}$ exposure from gas appliances and the prevalence of respiratory symptoms [24]. Our results also suggested that exposure to $\mathrm{NO}_{2}$ was related to gas heating during winter.
Although the effect of $\mathrm{NO}_{2}$ exposure on snoring was significant even after adjustment for asthma, atopy and other confounding factors, caution must be taken when interpreting the $\mathrm{NO}_{2}$ findings and further investigation is required before they can be generalized to the pediatric population at large. A limitation of this cross-sectional study is that only $9 \%$ of the study sample was monitored for environmental testing due to budget and other constraints. Nevertheless, this subgroup of children did not differ significantly from the whole sample or other populations of young children in Perth $[25,26]$ with respect to home environment, respiratory symptoms and atopy. Secondly, the causal effects of $\mathrm{NO}_{2}$ could not be determined because the measurements of exposure and illness were taken at the same time. The assessment of snoring was retrospective in relation to the time of environmental monitoring. Moreover, the significant association between snoring and $\mathrm{NO}_{2}$ exposure in winter may be attributed to $\mathrm{NO}_{2}$ emission from gas heaters in conjunction with low ventilation during the winter season.

As for potential mechanisms for this association, there is little in the literature that can directly explain how exposure to $\mathrm{NO}_{2}$ might result in snoring. Although there is evidence to suggest that exposure to $\mathrm{NO}_{2}$ is associated with development of allergic disease [27], the observed association between $\mathrm{NO}_{2}$ exposure and snoring is independent of atopy. Snoring occurs due to upper airway obstruction during sleep. The obstruction commonly occurs at the level of the nasal turbinates as with anterior rhinitis or the nasopharynx due to adenoid hypertrophy. Exposure of airway epithelium in vitro results in the release of inflammatory cytokines and adhesion molecules [28]. Therefore, it is possible that exposure to $\mathrm{NO}_{2}$ increases upper airway inflammation, resulting in mucosal oedema and airway obstruction. Alternatively, upregulation of ICAM1 the primary ligand for rhinovirus [28] could increase the susceptibility to, or severity of upper respiratory tract infection, resulting in upper airway oedema and/or adenoid hypertrophy. Finally, it has been suggested that $\mathrm{NO}_{2}$ increases lipid membrane fluidity [29] that in turn can alter receptor-ligand interactions. Thus $\mathrm{NO}_{2}$ exposure might produce changes in cell-cell and cell-pathogen interactions that could result in altered upper airway physiology. Given the high prevalence of snoring in our population and the knowledge that snoring is a significant risk factor for obstructive sleep apnea, the mechanisms that might underpin the association between $\mathrm{NO}_{2}$ exposure and snoring require further study.

In conclusion, the present study shows that snoring is common among primary school children in Perth, and snoring is associated with other respiratory symptoms. Passive smoking increases the risk of snoring in children but pet ownership may decrease the risk. The level of 
nitrogen dioxide in domestic environment is positively associated with the prevalence of snoring in children.

\section{Authors' contributions}

GZ, JS, KR, SS Study design, coordination and management

\section{GZ, JS, KR Field measurement and laboratory work}

AHL, GZ Data analysis and interpretation of results

GZ, JS, KR, AHL, SS Preparation and revision of the manuscript

\section{Acknowledgements}

The authors are grateful to Mr Paul Dubois who supervised the laboratory analysis. Thanks are also due to Dr. Franklin and three anonymous reviewers for their constructive comments and suggestions.

\section{References}

I. Schechter MS: Technical report: Diagnosis and management of childhood obstructive sleep apnea syndrome. Pediatrics 2002, 109:e69.

2. O'Brien LM, Holbrook HC, Mervis CB, Klaus CJ, Bruner JL, Raffield T], Rutherford J, Mehl RC, Wang M, Tuell A, Hume BC, Gozal D: Sleep and Neurobehavioral Characteristics of 5- to 7-YearOld Children With Parentally Reported Symptoms of Attention-Deficit/Hyperactivity Disorder. Pediatrics 2003, I I I:554-563.

3. Nieminen P: Snoring and obstructive sleep apnea in young children: a 6-month follow-up study. University of Oulu, Department of Paediatrics 2002 [http://herkules.oulu.fi/isbn95 14266552/].

4. Lu LR, Peat JK, Sullivan CE: Snoring in preschool children: prevalence and association with nocturnal cough and asthma. Chest 2003, I 24:587-593.

5. Castronovo V, Zucconi M, Nosetti L, Marazzini C, Hensley M, Veglia F, Nespoli L, Ferini-Strambi L: Prevalence of habitual snoring and sleep-disordered breathing in preschool-aged children in an Italian community. J Pediatr 2003, I 42:377-382.

6. Kwok KL, Ng DK, Cheung YF: BP and Arterial Distensibility in Children With Primary Snoring. Chest 2003, I 23:| 56 |-I 566.

7. Tauman R, O'Brien LM, Holbrook CR, Gozal D: Sleep pressure score: a new index of sleep disruption in snoring children. Sleep 2004, 27:274-278.

8. Camhi SL, Morgan WJ, Pernisco N, Quan SF: Factors affecting sleep disturbances in children and adolescents. Sleep Med 2000, I:II7-I23.

9. Aittokallio T, Gyllenberg M, Polo O: A model of a snorer's upper airway. Math Biosci 200I, I 70:79-90.

10. Corbo GM, Fuciarelli F, Foresi A: Snoring in children: association with respiratory symptoms and passive smoking. BMJ 1989 , 299:|49|-|494.

I I. Rumchev K: Indoor environmental risk factors for respiratory symptoms and asthma in young children. In PhD thesis Curtin University, School of public health; 200I.

I2. Levin J, Andeerson K, Lindahi R, Nilsson C: Determination of subparts per million levels of formaldehyde in air using active and passive sampling on 2,4-Dinitrophenylhydrazine glass fibre and high performance liquid chromatography. Anal Chem 1985, 57:1032-1035.

13. Palmes ED, Gunnison AF, Dimattio J, Tomaczyk : Personal sampler for nitrogen dioxide. Am Ind Hyg Assoc J 1976, 37:570-577.

14. Chauhan AJ, Inskip HM, Smith S, Schreiber J, Johnston SL, Holgate ST: Personal exposure to nitrogen dioxide $\left(\mathrm{NO}_{2}\right)$ and the severity of virus-induced asthma in children. Lancet 2003, 36 I:1939-1944.

15. Koo LC, Ho JH, Ho CY, Matsuki H, Shimizu H, Mori T: Personal exposure to nitrogen dioxide and its association with respi- ratory illness in Hong Kong. Am Rev Resp Dis 1990, |41:| | 19-1 I26.

16. Anuntaseree W, Rookkapan K, Kuasirikul S, Thongsuksai P: Snoring and obstructive sleep apnea in Thai school-age children: prevalence and predisposing factors. Pediatr Pulmonol 2001, 32:222-227.

17. Brunetti L, Rana S, Lospalluti ML, Pietrafesa A, Francavilla R, Faneli M, Armenio $L$ : Prevalence of obstructive sleep apnea syndrome in a cohort of I,207 children of southern Italy. Chest 200I, I 20:1930-1935.

18. Ng DKK, Kwok KL, Poon G, Chau KW: Habitual snoring and sleep bruxism in a paediatric outpatient population in Hong Kong. Singapore Med J 2002, 43:554-556.

19. Larsson LG, Lindberg A, Franklin KA, Lundback B: Symptoms related to obstructive sleep apnoea are common in subjects with asthma, chronic bronchitis and rhinitis in a general population. Respir Med 200I, 95:423-429.

20. McColley SA, Carroll JL, Curtis S, Loughlin GM: High prevalence of allergic sensitization in children with habitual snoring and obstructive sleep apnea. Chest 1997, I I I: I70- I73.

21. Shin C, Joo SJ, Kim J, Kim T: Prevalence and correlates of habitual snoring in high school students. Chest 2003, I 24:1709-I7I5.

22. Hesselmar B, Aberg N, Aberg B, Eriksson B: Does early exposure to cat or dog protect against later allergy development? Clin Exp Allergy 1999, 29:61 1-617.

23. WHO: Air Quality Guideline for Europe. WHO Regional Publications Second2000. European Series, No. 91

24. Ciuk J, Volkmer RE, Edwards JW: Domestic nitrogen oxide exposure, urinary nitrate, and asthma prevalence in preschool children. Arch Environ Health 200I, 56:433-438.

25. Oddy WH, Holt PG, Sly PD, Read AW, Landau LI, Stanley FJ, Kendall GE: Association between breast feeding and asthma in 6 year old children: findings of a prospective birth cohort study. BM] 1999, 3 19:815-819.

26. Rumchev K, Spickett J, Bulsara M, Phillips M, Stick S: Association of domestic exposure to volatile organic compounds with asthma in young children. Thorax 2004, 59:746-75I.

27. D'Amato G, Liccardi G, D'Amato M, Cazzola M: Respiratory allergic diseases induced by outdoor air pollution in urban areas. Monaldi Arch Chest Dis 2002, 57:161-163.

28. Pathmanathan S, Krishna MT, Blomberg A, Helleday R, Kelly FJ, Sandstrom T, Holgate ST, Wilson SJ, Frew AJ: Repeated daily exposure to 2 ppm nitrogen dioxide upregulates the expression of IL5, IL-I 0, IL-I3, and ICAM-I in the bronchial epithelium of healthy human airways. Occup Environ Med 2003, 60:892-896.

29. Patel JM, Edwards DA, Block ER, Raizada MK: Effect of nitrogen dioxide on surface membrane fluidity and insulin receptor binding of pulmonary endothelial cells. Biochem Pharmacol 1988, 37:1497-1507.

\section{Publish with Bio Med Central and every scientist can read your work free of charge}

"BioMed Central will be the most significant development for disseminating the results of biomedical research in our lifetime. "

Sir Paul Nurse, Cancer Research UK

Your research papers will be:

- available free of charge to the entire biomedical community

- peer reviewed and published immediately upon acceptance

- cited in PubMed and archived on PubMed Central

- yours - you keep the copyright 